The Historical Journal, 64, 3 (2021), pp. 774-795 (c) The Author(s), 2020. Published by Cambridge University Press. This is an Open Access article, distributed under the terms of the Creative Commons Attribution licence (http://creativecommons.org/licenses/by/4.o/), which permits unrestricted re-use, distribution, and reproduction in any medium, provided the original work is properly cited.

doi: $10.1017 /$ Soo $18246 X_{20000400}$

\title{
THE LEBANESE STUDY COMMITTEE: A CHRISTIAN THINK TANK IN WARTIME LEBANON ( $\left.1975^{-1982}\right)$
}

\author{
CHLOE KATTAR \\ University of Cambridge
}

\begin{abstract}
A B S T R A C T. This article seeks to shed light on the Lebanese Study Committee, an overlooked centre of intellectual production and political activity during the Lebanese Civil War. It was comprised of legal experts and Maronite monks of the Lebanese Maronite Order, and emerged at the Holy Spirit University of Kaslik in 1975. The committee was created at the initiative of the Catholic clergy in order to endow the Christian war effort with an 'intellectual pole' capable of studying recent developments and provide solutions aimed at defending the interests of the Christian society. By making use of hitherto inaccessible primary sources, its internal and external publications, the article elucidates the activities and ideas of the committee, which worked to counteract leftist discourse and propaganda. By paying attention to the context of the Lebanese Study Committee's emergence, the article also brings to light a history of interaction between lay, clerical, state, and para-military institutions. It concludes that its creation is the direct consequence of the grassroots mobilization of conservative agents, which is reminiscent of the ways in which Western conservatism was revived in the same years.
\end{abstract}

The bloody events of 13 April 1975 marked the start of the Lebanese Civil War, which saw Christian militias pitted against the Lebanese National Movement (LNM), the alliance of 'Muslim-progressive' organizations and the Palestinian Fedayeen. In the months between April and the end of the summer of 1975, a series of meetings was held at the Holy Spirit University of Kaslik (USEK) at the invitation of the monks of the Lebanese Maronite Order (OLM), based at the university as part of the teaching staff. Abbot Paul Naaman (Na'man), who served as dean of the Faculty of History and Archaeology, and Abbot Sharbil Kassis, vicar general of the congregation, 'held periodical open-ended meetings' that were attended by professors, journalists, lawyers, businessmen, and many others from the Christian establishment. ${ }^{1}$ The OLM was one of the

Darwin College, Cambridge, CB39EU ck5I I@cam.ac.uk

${ }^{1}$ Father Thomas Mhana (ex-LSC secretary), in discussion with the author, February 2018 , USEK, Lebanon. 
oldest monastic orders in Lebanon, and the most politically committed, and the aim of these meetings was to come up with a concerted answer to the unfolding crisis. ${ }^{2}$ This was the first of countless meetings between various Christian intellectuals and the OLM monks, which would continue throughout the war, thanks to the strategic location of USEK. Situated in the Christian hinterland, twenty kilometres east of Beirut, it was far enough from the fighting that intellectuals could continue to meet safely there. This small, eclectic nucleus of intellectuals and monks would subsequently form the Lebanese Study Committee (LSC), which acted during the war as a Christian think tank, by meeting regularly to formulate advice on strategy for the Lebanese Front, the coalition of major conservative Christian parties, including the two most prominent ones, the National Liberal Party (PNL) of Camille Chamoun (Sham'un) and the Lebanese Phalanges of Pierre Gemayel (Jummayil).

By examining the intellectual and political context of the formation of the LSC, the article aims to demonstrate how military confrontation brought about a radicalization of Christian political thought. It charts the revival of Lebanese Christian conservatism after a seemingly peaceful period of Muslim-Christian co-existence following independence (apart from the $195^{8}$ crisis): first, by documenting the establishment, lineage, and role of the LSC within the Christian political landscape, and second, by identifying the central tenets that characterized its wartime discourse. By highlighting the prevalence of Christian conservatism in the Middle East, the article provides the general reader with an insight into the content of right-wing thought outside the West. In doing so, it also helps to elucidate the broader political developments of the 1970s, a decade usually associated with the rise of Western conservatism. ${ }^{3}$ The establishment of the LSC in 1975, through the grassroots mobilization of conservative agents, as a Christian policy institute dedicated to counteracting leftist propaganda, is reminiscent of the efforts of the New Right or the Nouvelle Droite in the same period.4 As a result, this article argues that the reinvigoration of the Christian Right in the 1970 s needs to be reconceived as a global event, rather than one confined to the United States, France, and other Western countries. Growing anxieties and concerns over the moral decline of society in the 1970 - a decade marked by increasing globalization - rekindled the links between right-wing thought and religious thought in the Middle East and the West.5 Such existential threats

\footnotetext{
${ }^{2}$ The monks and nuns of the Order use the post-nominal initials of OLM, from the French version of the name, Ordre Libanais Maronite.

3 Bruce J. Schulman and Julian E. Zelizer, eds., Rightward bound: making America conservative in the I97os (Cambridge, 2009).

4 Julian E. Zelizer, 'Rethinking the history of American conservatism', Reviews in American History, $3^{8}$ (2010), pp. 367-92; Daniel K. Williams, God's own party: the making of the Christian right (Oxford, 2010); J. G. Shields, The Extreme Right in France, from Petain to Le Pen (New York, NY, 2007).

5 Niall Ferguson et al., The shock of the global: the I97os in perspective (Cambridge, 2010).
} 
were deeply felt by Lebanese Christians from the late 1960 onwards, as they saw the armed Palestinian presence and the political ascendency of the Arab left in their country as a direct menace to the Lebanese entity.

The aim of the article, however, is not to offer a comparative study of Lebanese and Western conservative groups, but rather to use the LSC as a case-study for Lebanese Christian conservatism and to call for further consideration of the global aspect of the rise of conservatism in the 1970s. Viewing Lebanese conservatism through a global lens, moreover, allows for a better understanding of its peculiarities. Many scholars have argued for the 'exceptionalism' of the national variant of conservatism they have studied. In The right nation, for example, John Micklethwait and Adrian Wooldridge remark that 'most Americans still do not realize how extraordinary their brand of conservatism is'. ${ }^{6}$ The same has been said about the French Right, described as a set of cultural 'sensibilités' and attachments to traditional values such as the family, the région, and the church, among others. 7 But the same scholars also point to the existence of core principles in the conservative credo. These are best summarized by the much-cited 'creed of Edmund Burke', which 'might be crudely reduced to six principles: a deep suspicion of the power of the state, a preference for liberty over equality, patriotism, a belief in established institutions and hierarchies, scepticism about the idea of progress, and elitism'. ${ }^{8}$ I argue that Lebanese conservatism, like many of its counterparts, can be studied through its similarities and dissimilarities to this vague 'classical conservatism'. The LSC's preference for pragmatism and long-standing political arrangements, its dismissal of 'progressive' reforms, and its staunch ethno-nationalism suggest an adherence to a universal conservative tradition. But the Lebanese case stands out thanks to some distinctive concepts, such as the defence of sectarian representation, a belief in the 'inerrancy' of the Lebanese constitution, and the espousal of communities as intermediate structures between the citizen and the state. Most importantly, by examining the understudied topic of Christian conservatism in the Middle East, this article challenges the historiographical markers usually associated with Arab intellectual history, mostly studied through the cases of Arab nationalism and leftist thought. 9

Much of the scholarly attention the Lebanese Civil War has received has concentrated on political and international actors, with a strong focus on Syrian and Israeli involvement, but also on American-Soviet tensions, as the war was

${ }^{6}$ John Micklethwait and Adrian Wooldridge, The right nation: conservative power in America (New York, NY, 2004), p. 12.

7 Jean-Francois Sirinelli, ed., L'histoire des droites en France, II (Paris, 1992).

8 Micklethwait and Wooldridge, The right nation, p. 13.

9 George Antonius, The Arab Awakening: the story of the Arab national movement (Philadelphia, PA, 1939); Albert Hourani, Arabic thought in the liberal age, I798-1939 (Cambridge, 2016); Fadi Bardawil, Revolution and disenchantment, Arab Marxism and the binds of emancipation (Durham, NC, 2020). 
both an internal affair and a regional conflict. ${ }^{10}$ Indeed, the main works of reference have focused predominantly on the actions of the $z$ ' $a m a$ - the main political leaders in the various religious communities - and have traced the political and military histories of the war. ${ }^{11}$ The history of right-wing actors during the war, meanwhile, has been limited to the study of the main protagonists and their militias. ${ }^{12}$ Memoirs were for a long time a prevalent source of information, including accounts by various right-wing figures such as Camille Chamoun, who published his war diaries; militiaman Robert 'Cobra' Hatim; and even some men operating within the LSC, such as Abbot Naaman. ${ }^{13}$ These aside, the figure of Bashir Gemayel dominates the literature, with many works attempting to explain his rapid rise to power. ${ }^{14}$

This article seeks to turn the lens of scholarly inquiry back upon the intellectual and social histories of the war, by examining how a specific group of intellectuals took up the ideological battle and tried to influence both decision-makers and public opinion with their writings. There have been no studies on Christian intellectuals during the war, and although this article touches upon the relationship between politicians and literati, it places the main spotlight on the latter. And when research has been conducted on intellectuals during the war, it has centred on leftist figures such as socialist leader Kamal Jumblatt and Marxist intellectual Mehdi Amil. ${ }^{15}$ As Michael Kazin notes in his overview of studies on American conservatism - published before the recent historiographical revival - 'Historians, like most people, are reluctant to sympathize with people whose political opinions they detest', which explains why 'intellectual discourse about the [American] Right tended to fix on the notion of "extremist" or "radical" factions'. ${ }^{16}$

The same could be said about the Lebanese Right, often associated with concepts such as fascism, sectarianism, and xenophobia. ${ }^{17}$ But this is a simplistic

${ }^{10}$ Adeed Dawisha, Syria and the Lebanese crisis (London, 1980); Ralph A. Hallenbeck, Military force as an instrument of U.S. foreign policy: intervention in Lebanon, August I982-February I984 (New York, NY, 1991).

${ }^{11}$ Kamal S. Salibi, Crossroads to civil war: Lebanon, 1958-1976 (New York, NY, 1976); Samir Kassir, La guerre du Liban, de la dissension nationale au conflit regional (Paris, 1994).

${ }^{12}$ Judith Harik, The public and social services of the Lebanese militias, Centre for Lebanese Studies, vol. 14 (Oxford, 1994).

13 Camille Chamoun, Crise au Liban (Beirut, 1977); Robert Hatem, From Israel to Damascus: the painful road of blood, betrayal and deception (n.p., 1999); Antoine Saad, Mémoires du Père Abbé Boulos Naaman, des accords du Caire à l'assassinat de Bachir Gemayel (Paris, 2015).

14 Selim Abou, Bechir Gemayel ou l'esprit d'un peuple (Paris, 1984); Alain Menargues, Les secrets de la guerre du Liban, du coup d'état de Béchir Gémayel aux massacres des camps palestiniens (Paris, $2004)$.

${ }^{15}$ Farid al-Khazen, 'Kamal Jumblatt, the uncrowned Druze prince of the Left', Middle Eastern Studies, 24 (1988), pp. 178-205; Samer Frangie, 'Theorizing from the periphery: the intellectual project of Mahdi 'Amil', International Journal of Middle East Studies, 44 (2012), pp. 465-82.

${ }_{16}$ Michael Kazin, 'The grass-roots Right: new histories of U.S. conservatism in the twentieth century', American Historical Review, 97 (1992), pp. 136-55, at pp. 136-7.

17 Callum Hutchinson, 'Can the Lebanese Phalange be considered a fascist movement? A critical examination using Stanley G. Payne’s typology of fascism', Undergraduate Journal of Near Eं Middle Eastern Civilizations, 11 (2018-19), pp. 20-37. 
reading of the Lebanese Right, which focuses on its 'excesses', whether because of the bloody history of its militias or because of the spotlight shone on radical figures with eccentric ideas, such as the ultra-nationalistic poet Sa'id 'Aql, who created a Lebanese language and alphabet. ${ }^{18} \mathrm{But}$, as Kazin reminds us, the extremist label does not always apply to "conservatives, who were men of ideas, "temperate and compromising"". ${ }^{19}$ The lay intellectuals of the LSC could be said to fit this description, as their aim was to formulate a wellrounded and articulate conservative discourse, designed above all to compete as an acceptable alternative to the attractive leftist rationale.

It is no surprise then that the LSC is practically absent from the literature on the war, only mentioned in passing. In his book on the Maronites in wartime Lebanon, leading Phalangist intellectual Joseph Abou Khalil refers to the location 'Kaslik' rather than to the LSC as a body of researchers when discussing the intellectual preparations taking place at the university. ${ }^{20}$ Likewise, Alexander Henley, in his study on the Maronite church at war, describes the organization as the 'Research Committee of Kaslik' or the 'Kaslik group'. ${ }^{21}$ Although Henley recognizes that the group acted as a 'prominent ideological think-tank', he does not expand on how it worked and offers little insight into the writings of the LSC. ${ }^{22}$ The LSC is generally portrayed as a vassal organization of larger Christian groups: Yara al-Khury's unpublished thesis testifies to the pioneering nature of LSC ideas, as illustrated by its participation in the famous Saydit al-Bir seminar, but is a study devoted to the Lebanese Front. ${ }^{23}$ The relative absence of the LSC in the historiography is also due to the long unavailability of sources: it was only in 2018 that the USEK Libraries granted public access to the papers of Abbot Thomas Mhana, ex-secretary of the LSC. This article is thus the first scholarly work to make use of the minutes of LSC meetings and to cross-reference these with the committee's published writings.

This article therefore represents the first attempt at writing a fully fledged history of the LSC, exploring its genesis, its modes of functioning, and the identities of its most prominent members. Most importantly, the article differs from the bulk of the literature by focusing on the lay intellectuals of the LSC. Henley, who looks at the internal politics of the Maronite church, focuses on the monks who played a key role in the LSC: Abbots Kassis and Naaman. ${ }^{24}$ Instead, thanks in part to interviews conducted with two ex-members, Walid al-Khazin and Khayrallah Ghanim, this article shifts the attention to previously unknown

18 Arkadiusz Plonka, L'idée de langue libanaise d'après Sa 'id 'Aql (Paris, 2004).

19 Kazin, 'The grass-roots Right', p. 137.

${ }^{20}$ Joseph Abou Khalil, Les Maronites dans la guerre du Liban (Paris, 1992), p. 89.

21 Alexander D. M. Henley, 'Politics of a church at war: Maronite Catholicism in the Lebanese Civil War', Mediterranean Politics, 13 (2008), pp. $353^{-69}$, at p. 357.

22 Ibid.

23 Yara al-Khury, 'La genèse du Front Libanais' (Ph.D. thesis, Saint-Joseph University, Beirut, 2014), pp. 333-417.

${ }^{24}$ Henley, 'Politics of a church', pp. $35^{6-8 .}$ 
LSC figures. By drawing on their recollections, the article allows their individual voices to emerge in a bid to give added texture to the story of the LSC by bringing its main characters to life. By 'contextualizing the individual experiences in the narrative of the war, oral history adds texture' and layers to an otherwise homogenizing narrative. ${ }^{25}$

This article, however, does not fall under the category of memory studies, as it does not concern itself with how facts are remembered by the intellectuals, but rather with how their testimonies can help us better understand the past. Indeed, 'information gained from interviews can force historians to rethink what they thought they knew', as oral history can reveal 'the small but telling details that previously escaped notice'. ${ }^{26}$ Testimonies by lay intellectuals not only reveal the inter-Christian tensions that existed during the war, but also allow for a variety of Christian accounts to emerge. The literature on Lebanese Christians during the war has mainly stressed the overwhelming popularity of the Phalangists' position, but the LSC formulated from within a strong criticism of their leader.

The lack of previous studies on the LSC compels this article to excavate carefully the context of its emergence. To achieve effective contextualization, the article sheds light on the LSC's paramilitary origins, as its establishment in 1975 was the result of pre-war preparations by the Maronite clergy. It then offers insight into the writings of the research centre: LSC texts were published from 1975 to 1977 but Naaman's memoirs show that it existed until 1982. ${ }^{27}$ Finally, to articulate fully the policies advocated by the LSC, the article explores how it related to other prominent players such as the patriarch, the Christian parties, the zu'ama, and the militias. In doing so, the article prioritizes and centres the LSC in an effort to reverse the usual historiographical paradigm and demonstrates how it progressively delegitimized the authority of the Lebanese Front. By remaining attentive to the singularity of the LSC's voice within the Christian landscape, the article thus opposes those readings of the war that characterize it as a conflict between two monolithic blocs-Muslims and Christians - and reveals the committee's insights and interventions in an internal Christian conversation and a national Lebanese one.

The concept of 'generation', as theorized by Karl Manheim, is the most useful tool for identifying the peculiarity of the LSC at these two levels. The committee's lay intellectuals formed a group of individuals of similar age who witnessed a major historical event unfold - the Civil War - when they were in their thirties. ${ }^{28}$ As a result, the LSC intellectuals can easily be classified as part of what is usually referred to in colloquial Lebanese as the jil al-harb (war generation),

${ }^{25}$ Megan Hutching, 'After action: oral history and war', in Donald A. Ritchie, ed., The Oxford handbook of oral history (New York, NY, 2011 ), p. 242.

${ }^{26}$ Donald A. Ritchie, 'Introduction: the evolution of oral history', in Ritchie, ed., The Oxford handbook, p. 12.

27 Saad, Mémoires du Père, p. 344.

28 Ghanim was born in 1943 and Khazin in 1946. 
or what Manheim describes as a 'generation as actuality'. ${ }^{29}$ However, LSC intellectuals can be considered a specific 'generational unit' - which, according to Manheim, 'represents a much more concrete bond than the actual generation' in comparison with the leftist or Muslim intellectuals, as 'youth...within the same actual generation... [can] work up the material of their common experiences in different specific ways'. $3^{\circ}$ Indeed, the LSC interpreted the war as the result of two destructive phenomena, namely the breakdown of the Lebanese state and the growing Palestinian threat, while, in contrast, 'progressive' intellectuals thought it necessary to topple sectarianism and bring about political reform.

Second, although LSC intellectuals shared with other Christian groups the same feeling of existential threat, they had their own generational perspective. Within the Christian landscape, the LSC seems to fit Manheim's concept of the concrete group, 'a nucleus... which has developed the most essential new conceptions which are subsequently developed by the unit'. The concrete group also comes into being by 'mutual stimulation in a close-knit vital unit'. $3^{1}$ Only the consideration that members of the Christian camp were internally stratified allows for a clear understanding of the singularity of the LSC: their age group allowed some lay intellectuals to develop a feeling of estrangement towards what they termed the traditional politics of the older Christian zu'ama, and their 'location' in the specific class of intellectuals made them consciously aware of the existence of the LSC as a separate group.

One last word on terminology. The members of the LSC were mostly Maronites, as was most of the Christian leadership. But non-Maronite Christians took part at all levels of the Christian war effort: Charles Malik, a Greek Orthodox, was one of the most eminent figures of the Lebanese Front. The use of the terms Christian and Maronite interchangeably in this article should be taken not as a dismissal of this fact, but rather as a way to stay true to and reflect the essence of wartime discourse. LSC intellectuals deliberately spoke on behalf of all Christians in their own texts, not only because Maronites had historically committed to representing all Lebanese Christians, but also because they were responding to very specific accusations coming from the Left, which conflated the slogan 'Christian privileges' with that of 'political Maronitism'. The same can be said for the use of concepts such as 'rightwing', 'conservative', or 'traditional': these were employed by their rivals to designate Christian parties for deliberate polemical purposes. If the Lebanese Right is the generic term used to designate broadly the political coalition of a variety of Christian groups, including the Phalanges, PNL, LSC, and Lebanese Front, Christian conservatism is employed here to define political ideology rather than

${ }^{29}$ Karl Mannheim, 'The problem of generations', in Essays on the sociology of knowledge (London, 1952), pp. 276-320, at p. 303.

30 Ibid., p. 304 .

$3^{1}$ Ibid., p. 307 . 
affiliation. Scholars employ the terminology used by their subjects not only to unpack the meanings invested in it but also for heuristic purposes. Only by navigating these various concepts is this article able to highlight the ideological nuances that existed within the Christian camp, and which went unperceived by the Left. The LSC is an example of a Christian think tank that supported the right-wing coalition (the Lebanese Front), but nonetheless opposed its traditionalism, while formulating its own brand of conservatism, inspired by its legal expertise and reflecting generational renewal.

\section{I}

The history of the LSC begins with an encounter with the patriarch rather than with the monks. In the late 1960 s, Walid al-Khazin, a future member of the LSC, and other students from the Huvelin Law Faculty were worried about the passivity with which the Christian zu'ama were reacting to the growing armed Palestinian activity and advocated a more resolute response..$^{2}$ This pushed Khazin and his peers to pay a visit to the Maronite patriarch in 1969. Khazin hailed from a prominent Maronite family, one that had held a great deal of political and economic sway for several centuries, and that had long fostered close relations with the Maronite church. The church had, after many attempts throughout the nineteenth century, succeeded in establishing itself as the mouthpiece of the community. 33 As a result, the patriarch had played a leading role in pre- and post-independence affairs, often finding himself at odds with political leaders. Patriarch Paul M uchy exemplified this tradition: he had openly defied President Chamoun during the $195^{8}$ crisis and had demonstrated his willingness to participate in the resolution of national crises. $34 \mathrm{M}$ 'uchy was sensitive to the activists' concerns and advised them to get in touch with the monks of the OLM, who were best equipped to provide assistance to their small group. 35 Naaman, who welcomed Khazin in USEK in the summer of 1969, described these meetings as the starting point of 'all political and ideological movements that were born in Christian circles during the war' $3^{6}$ The revival of Lebanese conservatism thus relied from a very early stage on the co-operation of lay and clerical actors, which was also the case in the United States in the pre-Reagan era. 37

However, in contrast with the American case, Lebanese conservative agents first coalesced in the 1960 s to explore the military means with which to

$3^{2}$ Walid al-Khazin (ex-LSC member), in discussion with the author, July 2018, Rayfun, Lebanon.

33 Carol Hakim, The origins of the Lebanese national idea: 1840-1920 (Berkeley, CA, 2013).

34 Ephraim A. Frankel, 'The Maronite patriarch: an historical view of a religious Za'im in the $195^{8}$ crisis', Muslim World, 66 (1976), pp. $213^{-25}$.

35 Khazin, discussion (see n. 32 ).

$3^{6}$ Saad, Mémoires du Père, p. 36.

37 Williams, God's own party, ch. 6, passim. 
combat 'progressive forces'. Khazin reiterated to Naaman his dissatisfaction with 'Gemayel and Chamoun', who, in his words, were not 'ready to take the necessary measures' to address the precarious security situation. $3^{8}$ What Khazin had in mind when approaching the OLM was to discuss possible logistical support for the establishment of military training camps for Christian volunteers. Khazin stresses that in his youth he 'wanted to devote [himself] to the Resistance', and notes that the OLM owned large parcels of land in remote areas that could be transformed into military camps. 39 Khazin's desire to train was a consequence of his apprehension about what he called the 'Palestinian belt', the series of refugee camps surrounding Beirut from Tal alZa 'atar to Ouza i. $4^{\circ}$ Khazin's views were met with sympathy by the monks: according to his recollection, Naaman was 'bowled over by the idea', and in his memoirs, Naaman describes Khazin and his peers as 'young, motivated and truly worried about their country'. $4^{1}$ This suggests that the intellectual synergy between lay and clerical actors that characterized the LSC was born during the pre-1975 preparations.

Most importantly, Khazin could count on the moral and material support provided by the monastic order to achieve his aim. The USEK monks had already started to co-ordinate the military training of the 'Kisrwani youth' by facilitating the procurement of rifles and ammunition. $4^{2}$ Khazin, who hailed from Ghusta, a municipality of the Kisrwan district, took on a leading role in these preparation efforts when he acted as head officer in one of the training camps, benefiting from the help of another OLM monk, Abbot Martinos Saba, whom he describes as 'a man of action', and who was responsible for organizing training days. 43 On the other hand, the USEK monks were also personally involved at the local level in the 'intellectual awakening' of young Christians, organizing conferences and writing papers in a bid to ensure 'that the allegiance to Lebanon prevails over other religious or nationalist allegiances'.44 Khazin took part for instance in a three-day seminar held in the OLM convent of Saint-Antoine, which was dedicated to studying the 'threat posed by the Palestinians to the Lebanese entity'.45 Thus, from 1969 to $1975^{- \text {the year in }}$ which the LSC was officially founded-Khazin was closely associated with OLM activities designed to 'sensitize and mobilize the Lebanese youth in the face of the growing danger' $4^{6}$

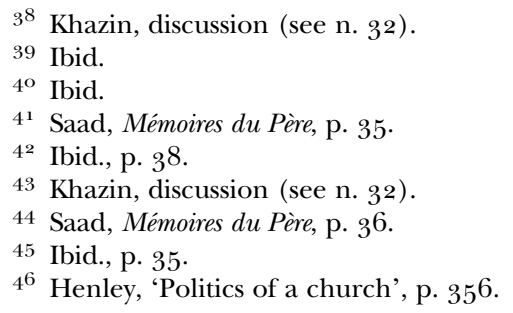


The emergence of the LSC must therefore be seen as the result of a grassroots awareness campaign spearheaded by OLM monks and targeting the Christian youth. Henley has noted the order's 'grassroots sympathies', pointing to the monasteries owned by the OLM to demonstrate that it 'commanded unparalleled grassroots support in the Christian villages'. 47 But it was the university especially, and the district of Kisrwan to a lesser extent, that was the focal point of the monks' multifarious efforts to prepare Christian society for war. $4^{8}$ The best illustration of the way in which the monks' 'proximity to the laity throughout the country allowed them direct involvement in events on the ground' was their ability to co-ordinate with the Kisrwani establishment through the USEK campus, as exemplified by Khazin. 49 Naaman and Kassis were not regular 'monastery' monks; they viewed themselves as 'monkspecialists', having conducted academic and liturgical research, and were lecturers and managers at USEK. $5^{\circ}$ This explains how they were able to attract segments of the Christian youth: not only did they make their convents and monasteries available for training activities of all sorts, but they also used USEK to 'spread the ideas developed by thinkers and intellectuals in our teaching spaces' and transformed it into an intellectual hub for Lebanese nationalist thought and Maronite particularism..$^{1}$

This was made possible, however, by the fact that such ideologies were attractive to the lay activists and in Christian society at large. The paramilitary origins of the LSC and Khazin's early itinerary demonstrate that even if the monastic orders were the 'populist elements within the...Church', their ideas were still popular among the Christian elite. ${ }^{2}$ Indeed, 'the distinctive Lebanese Maronite sense of mission' was not only the preserve of the monks, as lay intellectuals such as Khazin abided by it as well.53 Henley is right to observe that the militant stance of the OLM was the consequence of its distinctive pre-war identity. 54 But the local elite acted as an important partner of the monastic orders, encouraging actively its political interference. This was best articulated by LSC intellectuals, who fully supported the order's efforts despite the strict hierarchy prevailing within the Maronite church. Khazin himself was unimpressed by the newly elected patriarch, Peter Khuraysh, whom many considered to have 'faltered in his historical role' because of his moderate stance during the war, as he insisted on the separation between church and state.55 As a result, the orders were prompted during the war to assume the political role of the church.

\footnotetext{
47 Ibid., p. 357 .

$4^{8}$ USEK and Kaslik are located in the Kisrwan.

49 Henley, 'Politics of a church', p. $35^{6 .}$

$5^{\circ}$ Saad, Mémoires du Père, pp. 28-9.

$5^{1}$ Ibid., p. 39 .

$5^{2}$ Henley, 'Politics of a church', p. 353 .

53 Ibid., p. 355 .

54 Ibid., p. 354 .

55 Ibid., p. 353 .
} 
Khazin has particularly harsh words for Khuraysh, who proved not to be 'the strong leader we needed', and whose 'pro-Palestinian stance' he found unacceptable. $5^{6}$ Khazin remarks that, historically, 'Maronite chiefs would always act in accordance with the Patriarch', but the lack of initiative shown by Khuraysh was 'very frustrating for us'. 57 Khazin therefore judged it necessary for the monks to take on some of the patriarch's 'ecclesiastical' authority, an aim that would best be realized through the convening of the Permanent Congress of the General Superiors of the Eight Lebanese Orders and the Maronite League. $5^{8}$ While the Permanent Congress had been established in 1966, it began to be convened more frequently in the early years of the war.59 Khazin had been a member of the Maronite League before the war, and in this capacity attended some of these meetings of the Lebanese orders, which he considered very useful. ${ }^{60}$ At the heart of the LSC, therefore, was a relationship of reciprocal need between lay intellectuals and monks: the disillusionment caused by the 'abandonment' of the patriarchate created the need to establish new partnerships and structures to ensure the defence of Maronite interests.

\section{I I}

When the war broke out, the Permanent Congress convened in the presence of the Maronite League on 23 April. ${ }^{61}$ Composed of four Maronite Catholic and four Greek Melkite Catholic orders, the Permanent Congress was in a good position to take a representative public stand, and drafted a series of reports in the first months of the war aimed at clarifying the clergy's views and reassuring the Christian populace. It announced the formation, under the aegis of the monastic orders, of the LSC, a body to which the Permanent Congress delegated the task of monitoring events and writing reports. ${ }^{62}$ The committee's duty, as its name suggested, was to conduct an in-depth study of the Lebanese crisis in order to offer tangible solutions to the political leadership. The report stated that it 'brings together an elite of intellectuals which is trying to study the situation in order to reveal the truth and its deepest roots'. ${ }^{63}$ Subsequent reports

\footnotetext{
$5^{6}$ Khazin, discussion (see n. $3^{2}$ ).

57 Ibid.

$5^{8}$ Saad, Mémoires du Père, pp. 40-1.

59 Khazin, discussion (see n. $3^{2}$ ).

60 Ibid.

61 The Permanent Congress, al-Waqi al-Lubnani al-Qaim wa Mawqaf al-Ruhban Minhu (n.p., Apr. 1975), p. 3 .

62 The LSC, Mudhkara Sadira min Lijnat al-Buhuth al-Lubnaniyya hawl al-Mawqif al-Masihi min al-Awda' al-Lubnaniyya al-Qaima Yarfa'uha Mu'tamar al-Ru'sa' al-'Amin al-Da'im Li-l-Rahbaniyyat al-Lubnaniyya wa-l-Rabita al-Maruniyya il-al-Sadat Nuwab al-Umma al-Lubnaniyya (Beirut, 3 Nov. 1975 ), p. 2.

63 Ibid., p. 1.
} 
from the Permanent Congress were drafted by the LSC and titled 'Notes of the Lebanese Study Committee'.

From April onward, many Christian literati, not only those from the Kisrwan, felt the need to join forces with the embryonic movement revolving around the Permanent Congress, which was 'largely dominated by the oldest and most powerfully endowed' order, the OLM. ${ }^{6} 4$ Abbot Thomas Mhana, the secretary of the LSC, claims that a great many people attended these meetings, hosted at USEK. ${ }^{6}$ Abbot Naaman affirms that in the summer of 1976, the university welcomed at times more than a hundred participants. ${ }^{66}$ In its formative period, therefore, the LSC was not as disciplined as portrayed in the report of the Permanent Congress and discussions about 'the future of the Christian community' quickly diverged in multiple directions, as indicated by the initial division of the LSC into four separate subcommittees. ${ }^{6} 7$ The draft organizational plan indicates that the orders envisioned a strict hierarchical structure, with each subcommittee dealing with a specific subject-education and culture, socio-economic affairs, publicity and media, and politics - reflecting the monastic desire to organize the nascent intellectual movement. ${ }^{68}$ However, Abbot Mhana confirms that only the political subcommittee persisted, eventually becoming the only active research body, known thereafter as the LSC. ${ }^{6}$

The LSC did not long remain in this 'flexible operating mode', as it was described by Naaman in his memoirs. $7^{\circ}$ By the end of 1976 , the LSC had been scaled down to a cadre of faithful intellectuals working directly with the clerical and political 'authorities'. Some of the sessions pertained to sensitive topics, such as the early discussions about Israeli logistical support, which necessitated a sense of trust and secrecy to prevent leaking of information. ${ }^{71}$ Abbot Mhana, who took minutes at the meetings, confirms that this fixed group of intellectuals sustained the LSC's research activities throughout the war. ${ }^{2}$ Among these were the following figures, who were appointed to sit on what was initially called the 'political, juridical and administrative subcommittee':73 Walid al-Khazin, Khayrallah Ghanim, Robert 'Abdo Ghanim, Nassim Tarabay, Victor Ghurayib, Jean Naffah, Abbot Mhana, Abbot Na'man, and Abbot Kazzi. Mhana also confirms that invitations were at times extended to other OLM monks, representatives of political parties, or officers of the Lebanese army,

${ }^{64}$ Henley, 'Politics of a church', p. $35^{6}$.

${ }_{5}$ Mhana, discussion (see n. 1).

${ }^{66}$ Saad, Mémoires du Père, p. 120.

${ }^{67}$ Mhana, discussion (see n. 1).

68 Thomas Mhana to Sharbil Kassis, ‘Talbiya li-Talab al-Ab al-Am.', 12 Nov. 1976, Kaslik, Lebanon, USEK University Special Collections, Thomas Mhana Archives, TM201 7-234 (hereafter Mhana Archives).

${ }^{69}$ Mhana, discussion (see n. 1).

$7^{\circ}$ Saad, Mémoires du Père, p. 120.

$7^{11}$ LSC, 'Ijtima' fi 12/11/1976', 12 Nov. 1976, TM2017-238, Mhana Archives.

$7^{2}$ Mhana, discussion (see n. 1).

73 Thomas Mhana to Sharbil Kassis, 'Talbiya li-Talab'. 
but that these were not 'fixed' members.74 Most importantly, Khazin and Ghanim were prominent figures in their own right: they are mentioned repeatedly throughout Na'man's memoirs, playing a key role in negotiations for the unification of the Christian militias in 1979 and 1980.75

It is important to draw attention here, in view of the subcommittee's first appellation, to the fact that Mhana described LSC members as 'specialists'. ${ }^{6}$ Indeed, the lay intellectuals of the LSC came for the most part from the legal sector: Khazin and Ghanim had studied law at the Saint-Joseph University (USJ) and were young barristers when the war broke out; 'Abdo Ghanim was a respected jurist and law professor; Nassib Tarabay was a judge and Jean Naffah was an ex-president of the Bar Association.77 The main exception was Victor Ghurayib, who was a university lecturer. Long-standing personal ties played a role in the Permanent Congress's early recruiting efforts, but were not the only driver. Khazin and Naaman had known each other before the war, but Ghanim, on the other hand, became acquainted with Naaman only when invited to USEK, and it would seem that his reputation as a constitutionalist was the deciding factor in his appointment. $7^{8}$ Abdo Ghanim had already been an established figure in the legal community before the war, having practised as a lawyer, judge, teacher, arbitrator, and consultant.79 These three different pre-war trajectories show that the monastic orders sought above all a consistent level of quality among those they brought into the LSC. The 'expertise' of the committee's members reflected the seriousness with which the clergy approached this enterprise. The consequence in the long run was that the LSC functioned as a specialized think tank, aimed at defending Christian prerogatives through legal sources and arguments. It was therefore among the first think tanks to emerge in the Middle East, as the concept was rather new in the 1970 .

The creation of the LSC as a non-profit policy centre (the intellectuals were not paid for their services) attests to the innovative ways in which the Lebanese Right organized during the war. This in turn allows us to draw parallels with the growing political organization of conservative agents around the globe. Indeed, the LSC functioned in very similar ways to the Council for National Policy, set up in 1981 in the United States as 'a policy-making think tank where Christian Right activists and administration officials could discuss areas of common concern'. ${ }^{80}$ Its members included lay conservative activists such as Paul

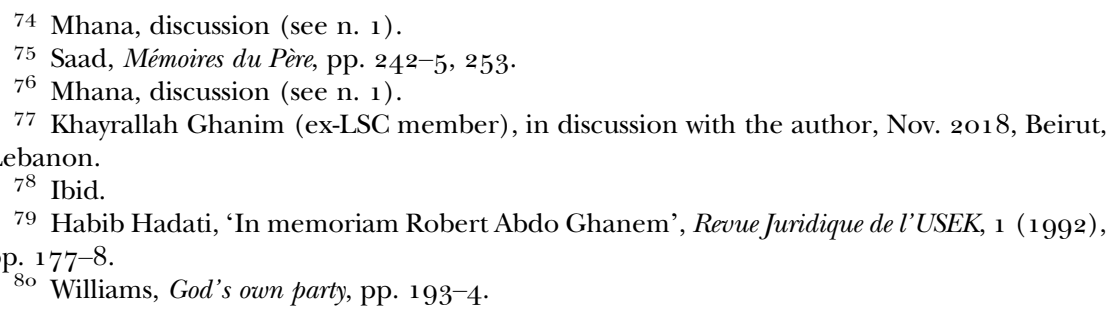


Weyrich and Richard Viguerie, but also clerical figures such as Southern Baptist pastor and televangelist Jimmy Falwell. ${ }^{81}$ Religious figures such as Falwell and Naaman played a similarly active role in the respective presidential campaigns of conservative candidates Reagan and Gemayel. ${ }^{82}$ Although Maronite Catholicism and American Evangelicalism are very different denominations, both clergymen wanted to increase lay Christian involvement in politics. $^{83}$ Like its American counterpart, the LSC was also formed as a means of answering and counteracting leftist propaganda. When Reagan was elected, the LSC concluded that the new administration should be informed that the OLM and their associates at USEK were different from leftist Lebanese Christians, such as those 'associated with the American University of Beirut'. ${ }^{4}$ The OLM wanted to promote USEK in contrast to Arab nationalist universities, but the creation of modular institutions such as the LSC or the Lebanese Front seemed like the next logical step for the clergy: it represented a clear attempt to create counter-institutions to those of their rivals, notably the LNM and the Palestine Liberation Organization.

The common professional background of its lay intellectuals provided for a productive mix of sympathy and synergy within the LSC, with Ghanim affirming that he and Khazin 'were always on the same page during LSC debates'. This in turn gave the committee a specific identity among Christian organizations, as its relative autonomy from the two major parties allowed members to express their opinions more freely. This distancing from both the PNL and the Phalanges was already visible in their pre-war trajectories. During the 1960 , Khazin and his peers at USJ had attempted to create a new political movement among Christian students. In the same vein, Ghanim had, before coming to the LSC, been an adviser to Raymond Edde (Iddi), leader of the National Bloc. ${ }^{85}$ Compared to the two other prominent Maronite leaders, Chamoun and Gemayel, Edde had always been a moderate figure, as indicated by his categorical refusal to participate in the armed conflict and his exile during the subsequent war years. ${ }^{86}$ The connection between Edde and Ghanim therefore illustrates the extent to which the 'younger' LSC members, Ghanim and Khazin, had chosen a 'middle way' in the Christian political landscape - that is, to engage in politics but to do so independently from the traditional parties. This was not an act of neutrality or non-alignment, as LSC intellectuals advocated armed conflict, but it reflected the scepticism of

81 Ibid.

82 Ibid., pp. 188-92; Saad, Mémoires du Père, pp. 227-9o.

83 Williams, God's own party, pp. 171-9.

84 Saad, Mémoires du Père, p. $3^{21 .}$

85 Ghanim, discussion (see n. 77).

86 Marie-Christine Aulas, 'The socio-ideological development of the Maronite community: the emergence of the Phalanges and the Lebanese Forces', Arab Studies Quarterly, 7 (1985), pp. $1-27$, at p. 18 . 
the younger generation regarding the ability of established Christian zu'ama to address the crisis.

\section{I $\mathrm{V}$}

The legal specialization of LSC members resulted in the use of a specific type of knowledge apparatus, which prioritized legal perspectives and language. This was reflected in the long reports they drafted and which were not simply opinion pieces, but rather 'analytical studies' that relied heavily on their mastery of Lebanese constitutionalism. Many of these reports were published in a series of booklets called al-Qadiyya al-Lubnaniyya (The Lebanese Cause). Some twenty-five booklets were published in total between 1975 and 1977, some written in French, but the majority in Arabic. No authorial information is included in the booklets, a standard editorial practice when giving the view of an organization. The al-Qadiyya project was all the more peculiar for being the initiative of the USEK monks rather than the intellectuals themselves: Ghanim confirms that it was Abbot Shikrallah Shufany who took care of collecting and publishing LSC reports. ${ }^{87}$ It was thus the editorial project of the clergy, which curated it to appeal to a readership of Christian sympathizers. For instance, the texts use the vocabulary of the 'resistance' to describe Christian fighters, in contrast to the 'collaborators' allied with 'the foreign [SyrianPalestinian] occupation forces', drawing a striking parallel with wartime France. ${ }^{88}$ Mhana recalls that the LSC intellectuals would always discuss collectively and suggest revisions to any text proposed individually, bolstering the LSG's image as a think tank under the auspices of the OLM. ${ }^{89}$

Although there is limited information on how the booklets were distributed and who read them, their publication indicates a desire to offer a counterpropaganda to the leftist discourse. The LSC was wary of the ongoing ideological battle for public opinion, and as early as November 1975 denounced the 'intellectual terrorism' of the left-wing press. $9^{\circ}$ Supported by Arab funds, these leftist journals were at an unfair advantage, given the very limited means of the nationalist press, which led the LSC to ask for state regulation of the printing presses..$^{11}$ In the same vein, publications like al-Qadiyya were created to compete with the media outlets of rival organizations, such as alWatan, the organ of the LNM. Thus, with al-Qadiyya, LSC intellectuals were

\footnotetext{
87 Ghanim, discussion (see n. 77).

${ }^{88}$ Khayrallah Ghanim, Walid al-Khazin, and Dimitri Trad, 'La solution', 22 Nov. 1975, Mhana Archives, TM201 7-255.

${ }^{89}$ Mhana, discussion (see n. 1).

$9^{\circ}$ LSC, 'Mudhkara hawl al-Mawqif al-Masihi min al-Awda' al-Lubnaniyya al-Rahina', 1 Nov. 1975, Mhana Archives, TM2017-026.

$9^{1}$ LSC, Mudhkara Sadira min Lijnat al-Buhuth al-Lubnaniyya hawl Islah al-Awda' al' Ama dimn Itar al-Sigha al-Lubnaniyya al-Qaima Yarfa'uha Mu'tamar al-Ru'sa' al-'Amin al-Qa'im li-lRahbaniyyat al-Lubnaniyya wa-l-Rabita al-Maruniyya ila-l-Sadat Nuwab al-Umma al-Lubnaniyya (Beirut, 11 Dec. 1975), pp. 11-13.
} 
able to regain control of the Christian narrative, as it was common for the leftist press to brand them as 'isolationists' or 'reactionaries'.$^{2}$ Several LSC reports were dedicated to shedding 'clear light' on the 'real dimensions' of the Lebanese crisis. 93 The reports attest to the LSC's tendency to present the war as an existential conflict between Christians and Muslims, and a struggle for the survival of the Lebanese state, in contrast to the LNM, which presented the conflict as one about civil and socio-economic rights.

Closer attention to Ghanim's own thought is helpful for contextualizing the development of LSC discourse. Ghanim wrote extensively for the LSC, as pointed out by Mhana, who claimed that he and 'Abdo Ghanim wrote the most, with Khazin also emphasizing Ghanim's 'theoretical rigour'.94 Ghanim's own experience as adviser to Edde in the short-lived National Dialogue Committee informed his later participation in the LSC. Its sessions had been dedicated to examining possible revisions that could be made to the Lebanese constitution, following the many calls for reform of the state made by the Lebanese Left. Ghanim, for his part, thought the constitution needed no amendment, observing that it was not simply a relic of French colonialism but the product of ' 200 years of history, as the need to enshrine the sociological plurality of Lebanese society in the constitution had emerged already during the Mount Lebanon Mutassarifate'.95 For Ghanim, sectarianism as a form of governance had stood the test of time because earlier generations of Lebanese had already experienced it, and 'had agreed to live according to these principles'. In 1974, he had published an article in the supplement of al-Nahar titled 'The Lebanese regime is one of the most effective and intelligent political regimes in the world', in which he praised sectarian representation..$^{6}$ The text was later reissued in al-Qadiyya with no authorial mark.97 Thus, LSC intellectuals defended sectarianism not only because it guaranteed Christian rights but also because they shared a 'certain kind of religious faith [and] respect for enduring and thus tested social hierarchies'. $9^{8}$

American and Lebanese conservatives thus had a similar reverence for their respective constitutions, with Ghanim and other LSC intellectuals also claiming the 'constitution was on [their] side'.99 They employed constitutional arguments to 'correct' the use of key concepts in enemy discourse, such as 'secularism', 'political confessionalism', and ‘communitarian privileges'. The first aim

$9^{2}$ Ibid.

93 LSC, 'Lumières franches sur la Question libanaise', al-Qadiyya al-Lubnaniyya, 3 ( 1976) (hereafter 'al-Qadiyya'); 'La crise libanaise dans ses principales dimensions', al-Qadiyya, 4 (n. d.).

94 Mhana, discussion (see n. 1); Khazin, discussion (see n. 32 ).

95 Ghanim, discussion (see n. 77).

$9^{6}$ Ibid.

97 LSC, 'Lubnan fi Nizamuhu al-Siyassi', al-Qadiyya, 2 (Nov. 1976).

$9^{8}$ David Farber, The rise and fall of modern American conservatism: a short history (Princeton, NJ, 2012 ), p. 2.

99 Micklethwait and Wooldridge, The right nation, p. 20. 
was to respond to the fundamental reproach portraying the Lebanese state as a haven of Christian privilege, and especially to the common complaint concerning the allocation of the presidency to the Maronites. Ghanim explains best the traditional argument used by Christians to justify this. The Maronite presidency, he insists, is the 'guarantee' of the 'Christian community within the pluralist structure, and eliminating it would alter the balance between communities by threatening the presence of its Christian constituency'. ${ }^{100}$ The LSC texts also emphasized that this privilege was in reality counterbalanced by the fact that the Sunni prime minister's signature was mandatory for all presidential decrees. ${ }^{101}$

To address the demand for the abolition of sectarian representation - which became a leitmotif of the LNM's discourse and had all the appeal of a modern and secular demand - LSC intellectuals also resorted to the 'enduring power' of the constitution. ${ }^{102}$ They stated that it recognized the existence of confessional groups as 'historical communities', interposed between the individual and the state (Articles 9, 10, and 95, as well as the Act of 2 April 1951), and that it also regulated the participation of these communities in central government (Articles 95 and 96, and Decree 112/59). ${ }^{103}$ The group claimed that this benefited Christians and Muslims equally by allowing them to remain autonomous in the fields of personal statute and education, thereby refuting the idea of an exclusively Christian 'sponsorship' of the regime. The report concluded that within this system, the Muslim claims were without merit, since both camps were already equal before the law, and 'alleged equality' could be claimed only within each group and not between them. ${ }^{104}$

The committee responded in a similar way to demands for secularization. LSC intellectuals did not reject the idea in theory, since the secular state was 'the most developed product of Western civilization'. ${ }^{105}$ Rather, they argued that the establishment of a secular state in Lebanon would require the transformation of the whole fabric of society from a sectarian to a homogeneous entity, which would be possible only after several generations. ${ }^{106}$ In addition, they remarked that on a constitutional level, this would require the abolition of the legal recognition of confessions as political entities and the unification of the Personal Statute Act, as well as agreement on educational and cultural policy. ${ }^{107}$ The intellectuals appealed to the honesty of their Muslim

${ }^{100}$ Ghanim, discussion (see n. 77).

${ }^{101}$ LSC, Mudhakra Sadira min Lijnat al-Buhuth al-Lubnanyyia al-Munbathiqa min Mu'tamar alBuhuth al-Lubnaniyya al-Kaslik hawl 'Arb' Siyagh Jadida Mumkina li-Bina' Lubnan al-Jadid (n.p., Oct. 1976), pp. $14^{-1} 5$.

${ }_{102}$ Micklethwait and Wooldridge, The right nation, p. 20.

103 Ghanim et al., 'Le grand danger', 22 Nov. 1975, Mhana Archives, TM201 7-255.

104 Ibid.

${ }^{105}$ LSC, 'Lubnan wa-l-Hawiya al- 'Arabiyya, Lubnan wa-l- Ilmaniyya', al-Qadiyya, 13 (1976),

p. 13.

${ }^{106}$ LSC, Mudhakra Sadira (Beirut: n.p., Oct. 1976), pp. 18-21.

107 Ibid. 
counterparts, given the intense resistance that such a radical change would provoke, especially within Muslim conservative circles. ${ }^{108}$ Thus, the LSC rejected the reforms demanded by the LNM in the name of realism and pragmatism, which in turn showed their deep 'scepticism about the idea of progress'-another tenet of classical conservatism. For Lebanese conservatives, most importantly, a unitary secular state would threaten the prerogatives of communities as intermediate structures between the citizen and the state. They shared with their American counterparts the belief that states should not interfere in the right of communities to control their cultural and spiritual affairs. In the mid-197os, Republicans were complaining against 'the federal government's "restrictive regulations" of local schools... as education belonged to local communities and parents', at a time when secular humanism was being demonized by the Christian Right. ${ }^{109}$

In another key strand of its counter-narrative, the LSC sought to demonstrate that Muslims benefited equally from communitarian privileges granted by the Lebanese state, in an effort to reveal the hypocrisy of enemy arguments. This was in part a reaction to the comparison made by Grand Mufti Hassan Khalid, 'one of the greatest Muslim dignitaries in the country', between the Lebanese Christians and the 'whites of Rhodesia' in front of French emissary the count of Merville during his visit to Lebanon in November $1975 .{ }^{1{ }^{10}}$ In order to discredit this juxtaposition of 'privileged' Christian and 'subjugated' Muslim communities, the LSC published a study summarizing all the privileges accorded to Muslim communities by the Lebanese state. ${ }^{111}$ The report placed particular emphasis on the exceptionally broad powers of the Muslim religious courts. The committee deplored the inaccuracy of Khalid's accusation, which conflated the economic privileges of a multi-confessional bourgeois class and the alleged political privileges of the Maronite community, placing all the blame on the latter. This defensive discourse was common to all Christian groups during the war, but LSC intellectuals prioritized legal sources in their writings, which made their discourse unique in the Christian landscape. The LSC then warned of the 'constitutional death of Lebanon' in the event of the realization of leftist demands, arguing that this would spell the end of Lebanon as it had existed since 1920. ${ }^{112}$

\section{$\mathrm{V}$}

For LSC intellectuals, however, attachment to traditional social structures did not entail attachment to the traditional political class. The LSC was mandated

108 Fawaz Traboulsi, Surat al-Fata bi-l-Ahmar (Beirut, 1997), pp. 154-5.

109 Williams, God's own party, p. 137.

110 LSC, 'Dirasa Tahliliyya li-Mawqaf al-Muslimin al-Lubnaniyyin min al-Harb al-Lubnaniyya al-Falastiniyya mundh Nisan 1975’, al-Qadiyya, 17 (1976), pp. $11-12$.

111 LSC, 'Dirasa Mujiza hawl ba'd Imtiyazat al-Tawa'if al-Islamiyya fi Lubnan', al-Qadiyya, 4 (n.d.).

112 Ghanim et al., 'Le grand danger'. 
to report to the Permanent Congress only in an advisory capacity, but the counsel it provided often turned into criticism of the Christian 'executive'. By articulating the LSC's relationship to the Lebanese Front, this article not only complicates our understanding of the front but also reveals the Christian intergenerational tensions. In his memoirs, Naaman describes the LSC as 'an affluent for the Lebanese Front', stressing its complementary and administrative role as it organized many of the front's meetings. ${ }^{13}$ Ghanim for instance had animated the preliminary discussions of the secret seminar of Saydit alBir, which took place from 21 to 23 January 1977, and which was dedicated to the reorganization of the front. ${ }^{114}$ Speaking on behalf of the LSC, Ghanim had advocated the adoption of some form of federalism as a way to guarantee Christian interests in the long term. ${ }^{15}$ In his intervention, however, Pierre Gemayel rejected firmly the avant-garde ideas of the intellectuals and reiterated his attachment to the 1943 Pact-also known as the power-sharing formula between the religious communities. ${ }^{116}$ Despite the fact that the orders backed the Phalangist stand "with all the material and moral resources at their disposal', lay intellectuals of the LSC disagreed with Pierre over ideology and strategy on many occasions throughout the war. The lay intellectuals advocated a new kind of politics, free of the practice of inter-elite negotiation or the 'overt pragmatism' of the traditional zu'ama, and which they later found embodied in Bashir. ${ }^{117}$ Bashir - the son of Pierre - had made his debut in the early years of the war as the supreme commander of the Lebanese Forces by joining together the various Christian militias. By gradually establishing himself as the uncontested Christian leader, he found himself in conflict with his father and the Phalanges as well as with rival militiaman Dany Chamoun from the PNL. ${ }^{118}$

LSC intellectuals started challenging the wartime decisions of Christian zu'ama very early on. In February 1976, the Syrian authorities helped produce the Constitutional Document, a proposal that conceded some internal reforms to the Lebanese power-sharing formula in return for guarantees that the Palestinian resistance would respect Lebanese sovereignty. This represented something of an about-face for Syria, which became more supportive of the Christian community. Bolstered by this support, the Christian leaders in return backed the Syrian move. However, the intellectuals and monks of the LSC were more suspicious of Syrian politics. The LSC response was published in al-Qadiyya. ${ }^{119}$ Naaman's recollection of the same episode is an interesting

\footnotetext{
113 Saad, Mémoires du Père, p. 120.

114 The Lebanese Front, 'al-Nass al-Rasmi li-l-Bayan al-lazi Aqarathu Khilwat Al-Jabha alLubnaniya', 23 Jan. 1977, Mhana Archives, TM201 7-267.

115 Al-Khury, 'La genèse du Front', p. 400.

116 Ibid., pp. 394-5. Riyad al-Solh in 1943 .

117 Saad, Mémoires du Père, p. $15^{6 .}$

118 Ibid., p. 159 .

119 LSC, 'Nass al-Wathiqa al-Dusturiyya wa-l-radd 'Alayha', al-Qadiyya, 11 (1976).
} 
case of selective use of archives as it downplayed the accusing tone of the initial LSC text. ${ }^{120}$ The authors stressed that it was inconceivable to discuss such vital elements of national security with a neighbouring state and its occupying army. They called for the rejection of the Syrian document, seeing it as the product of Syrian military domination, thus taking the same stance as the far-right militia the Guardians of the Cedars rather than joining forces with the traditional parties. ${ }^{121}$ The letter ended with the moral condemnation of all Christian $z u^{\prime}$ 'ama, declaring them responsible for this 'historic fall from grace' despite 'warnings from the LSC'. In contrast, Bashir's determination to openly defy the Syrians, as illustrated during the Hundred Days' War, won him the LSC's instant support. ${ }^{122}$

What LSC intellectuals could not approve of was the zu'ama's trend towards conciliation, as illustrated by the front's negotiations with Syria, whereas the committee was less prone to concessions with regard to Christian positions. ${ }^{123}$ An example of such political concessions is evident in Pierre's 'Letter to Lebanese Muslims', written in July 1976 and subsequently published in alQadiyya. ${ }^{124}$ In an attempt to ease sectarian tensions, Gemayel called for the revival of the 1943 Pact as a way to ensure power sharing within a single state entity. By that time, however, LSC intellectuals had already disavowed the 1943 Pact and were calling for the exploration of federalist structures. ${ }^{125}$ They became convinced that only a non-unitary form of state could guarantee Christian political interests, populations, and territories and that no intersectarian settlement should trump such a priority. ${ }^{126}$

In April 1976, al-Qadiyya published a booklet that evidenced their rejection of the 'politics of notables' personified by Pierre. ${ }^{127}$ The booklet presented itself as a mea culpa of sorts of the Christian camp. The LSC acknowledged the role played by the Christian community in the breakdown of the state, a confession absent from other official statements. This was not a sudden shift, as some lay intellectuals had been critical about the Christian zu'ama for years, as shown, for instance, in Khazin's various exchanges with the clergy before the war. Very quickly, the text levelled accusations at the Christian political parties in particular, accusing them of corruption and incapacity dating back to $1943 \cdot{ }^{128}$ A cherished idea among LSC intellectuals was that bad governance

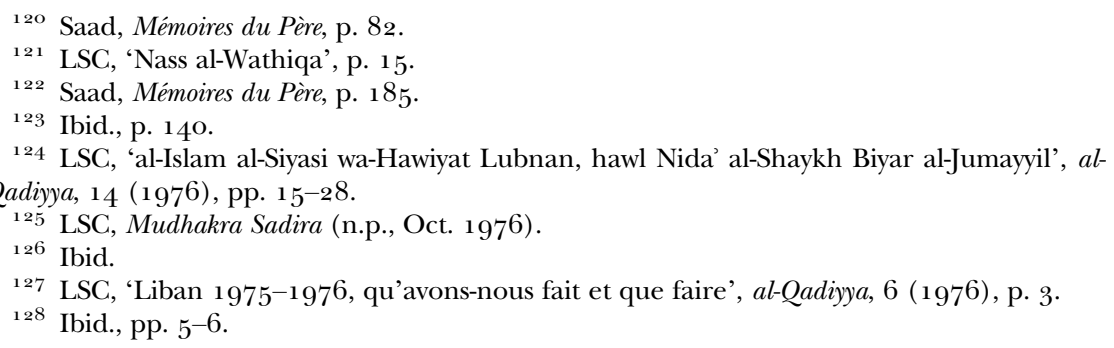


and the old political establishment, whether its Christian or its Muslim components, had killed the regime, rather than its political sectarianism. ${ }^{129}$

As a result, al-Qadiyya's eclectic and diverse publications reflected well the tensions generated by generational change in wartime Christian circles. As the LSC grew dissatisfied with old zu'ama, complaining in a letter to the Permanent Congress about 'the inefficiency of the [Lebanese] Front's leaders, who still haven't put an end to the chaos reigning in the country', they found in Bashir a like-minded leader. ${ }^{130}$ Bashir's new political style differed from that of traditional politicians. In his memoirs, Naaman highlighted Bashir's 'authenticity' and his ability to take the LSC's advice into consideration, which contrasted with the stubbornness that characterized his father. ${ }^{131}$ Most importantly, the acceptance of Bashir by the lay intellectuals of the LSC-although he was from the Gemayel family-can be seen as a direct consequence of their advocacy of more resolute and proactive Christian politics but also of generational renewal. He was almost exactly the same age as Khazin and Ghanim - he was born in 1947-and had attended the same Jesuit Francophone institution, the Huvelin Law Faculty. Khazin's opinion is especially enlightening in this respect. Because of his family legacy, Khazin was less inclined to develop feelings of allegiance towards other Maronite political families. He admits to having been hostile to the Phalanges in his youth, finding the party to be 'very populist'. ${ }^{132}$ But Bashir's emergence as a strong leader and his military prowess earned him special treatment and support from Khazin, who stresses that he was 'utterly convinced of his ability to lead us'. ${ }^{133}$

Last but not least, the LSC believed that a disciplined and prepared military was vital to Christian defence. Khazin himself had been involved in early military training, and he and Ghanim had taken part as mediators in the long-running negotiations aimed at the unification of the Christian militias under the Lebanese Forces umbrella. This became an urgent matter for the LSC after 1979, as evidenced by the many drafts in their archives of articles devoted to the unification project. ${ }^{134}$ In a context of growing clashes between militias, the LSC saw in Bashir a capable commander who could instil discipline and respect among fighters. The LSC also started to support Bashir's political ambitions: in 1977, the committee decided in secrecy to boycott the Lebanese Front in favour of Bashir, an event described by Naaman as a 'near coup d'état'. ${ }^{135}$

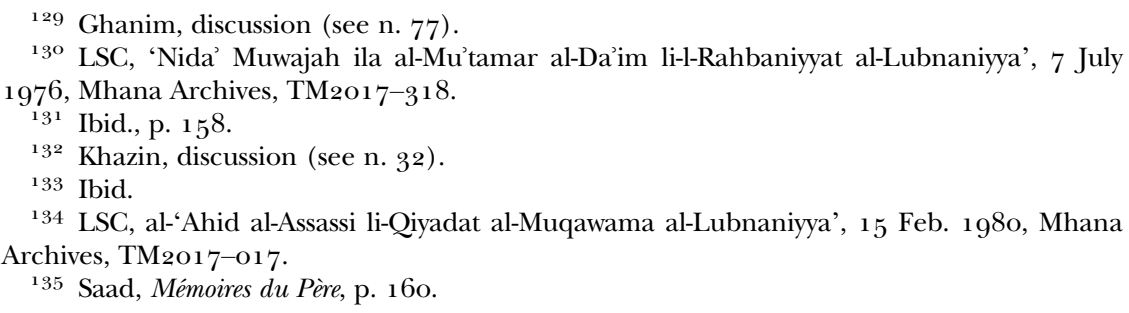


Therefore, it came as no surprise when the LSC fully backed his presidential campaign in 1982:136 this was due primarily to the lay intellectuals' belief in what they called 'the strategic value of legitimacy' as the Maronite presidency was the ultimate seat of executive power. ${ }^{137}$ Recent candidates such as Sulayman Franjiyyah had been a disappointment to Ghanim and Khazin, who sent him many letters in 1975 , urging him to take more drastic measures. ${ }^{1}{ }^{8}$ In one letter, they reminded him of 'the obligations of the president', urging him to assume his 'unique role of true leader'. ${ }^{39}$ Bashir, in contrast, personified the strong Christian leader the LSC had been calling for, and from 1982 onward, it strove to give his political ascension the stamp of constitutional legitimacy, which the LSC cherished above all.

\section{I}

This article has sought to shed light on the LSC, an overlooked centre of intellectual production and political activity during the Lebanese Civil War. By making use of hitherto inaccessible primary sources, the article elucidates the activities and ideas of the committee, which worked to counteract leftist discourse. By paying attention to the context of the LSC's emergence, the article brings to light a history of interaction between lay, clerical, state, and paramilitary institutions. It concludes that its creation as a policy institute, comprised of Christian legal experts, is the direct consequence of the grassroots mobilization of conservative agents, which is reminiscent of the ways in which Western conservatism was revived in the same years. Thus, through the LSC's case, the article argues that growing awareness of the necessity for political organization among conservative agents in the 1970 should be perceived as a transnational phenomenon. LSC writings, however, reveal the distinctiveness of Lebanese conservatism and the paradox lying at its core: its sovereignist stance and attachment to strong institutions such as the Maronite presidency and the constitution contradicts its espousal of communities as intermediate structures between the citizen and the state. Most importantly, the intellectuals grew critical of traditional Christian zu'ama, and their endorsement of Bashir Gemayel can be seen as a consequence of the generational renewal that took place in wartime Christian circles. All in all, the history of the short-lived LSC offers a more sophisticated account of the Civil War and is a contribution to the scholarship on post-colonial Lebanon and Arab intellectual history.

\footnotetext{
${ }^{136}$ Ibid., p. 349 .

137 Ghanim et al., 'Le grand danger'.

${ }^{138}$ Ibid.

139 Ibid.
} 